\title{
ESENSI PANCASILA DALAM KAJIAN SEJARAH BANGSA
}

\author{
AFAN ANANTA SHAKTI \\ afananantashakti03@gmail.com \\ 20220037 \\ STIE AKBP KBP PADANG
}

\section{A.Pendahuluan}

\section{1.latar belakang}

Pancasila adalah lima nilai dasar luhur yang ada dan berkembang bersama dengan bangsa Indonesia sejak dahulu.Sejarah merupakan deretan peristiwa yang saling berhubungan. Peristiwa-peristiwa masa lampau yang berhubungan dengan kejadian masa sekarang dan semuanya bermuara pada masa yang akan datang. Hal ini berarti bahwa semua aktivitas manusia pada masa lampau berkaitan dengan kehidupan masa sekarang untuk mewujudkan masa depan yang berbeda dengan masa yang sebelumnya.

Dasar Negara merupakan alas atau fundamen yang menjadi pijakan dan mampu memberikan kekuatan kepada berdirinya sebuah Negara. Negara Indonesia dibangun juga berdasarkan pada suatu landasan atau pijakan yaitu pancasila. Pancasila, dalam fungsinya sebagai dasar Negara, merupakan sumber kaidah hukum yang mengatur Negara Republik Indonesia, termasuk di dalamnya seluruh unsur-unsurnya yakni pemerintah, wilayah, dan rakyat. Pancasila dalam kedudukannya merupakan dasar pijakan penyelenggaraan Negara dan seluruh kehidupan Negara Replubik Indonesia.

Pancasila sebagai dasar Negara mempunyai arti yaitu mengatur penyelenggaraan pemerintahan. Konsekuensinya adalah Pancasila merupakan sumber dari segala sumber hukum. Hal ini menempatkan pancasila sebagai dasar Negara yang berarti melaksanakan nilai-nilai Pancasila dalam semua peraturan perundang-undangan yang berlaku. Berdasarkan latar belakang masalah di atas maka diangkat dalam bentuk makala yang berjudul "PANCASILA DALAM KAJIAN SEJARAH BANGSA INDONESIA". 


\section{Rumusan masalah}

\section{B.PEMBAHASAN}

\section{Pancasila Era Pra Kemerdekaan}

Asal mula Pancasila secara budaya,Menurut Sunoto (1984) melalui kajian filsafat Pancasila, menyatakan bahwa unsur-unsur Pancasila berasal dari bangsa Indonesia sendiri, walaupun secara formal Pancasila baru menjadi dasar Negara Republik Indonesia pada tanggal 18 Agustus 1945, namun jauh sebelum tanggal tersebut bangsa Indonesia telah memiliki unsurunsur Pancasila dan bahkan melaksanakan di dalam kehidupan merdeka. Sejarah bangsa Indonesia memberikan bukti yang dapat kita cari dalam berbagai adat istiadat, tulisan, bahasa, kesenian, kepercayaan, agama dan kebudayaan pada umumnya. (Sunoto, 1984: 1). Dengan rinci Sunoto menunjukkan fakta historis, diantaranya adalah :

1. Ketuhanan Yang Maha Esa : bahwa di Indonesia tidak pernah ada putus-putusnya orang percaya kepada Tuhan.

2. Kemanusiaan yang adil dan beradab : bahwa bangsa Indonesia terkenal ramah tamah, sopan santun, lemah lembut dengan sesama manusia.

3. Persatuan Indonesia : bahwa bangsa Indonesia dengan ciri-cirinya guyub, rukun, bersatu, dan kekeluargaan.

4. Kerakyatan yang dipimpin oleh hikmat kebijaksanaan dalam permusyawaratan/perwakilan : bahwa unsur-unsur demokrasi sudah ada dalam masyarakat kita.

5. Keadilan social bagi seluruh rakyat Indonesia : bahwa bangsa Indonesia dalam menunaikan tugas hidupnya terkenal lebih bersifat social dan berlaku adil terhadap sesama.

Pancasila sebagai dasar negara Republik Indonesia, ditetapkan pada tanggal 18 Agustus 1945 sebagai dasar negara, maka nilai-nilai kehidupan berbangsa, bernegara dan berpemerintahan sejak saat itu haruslah berdasarkan pada Pancasila, namun pada kenyataannya, nilai-nilai yang ada dalam Pancasila telah dipraktekkan oleh nenek moyang bangsa Indonesia dan kita praktekkan hingga sekarang. Hal ini berarti bahwa semua nilai-nilai yang terkandung dalam Pancasila telah ada dalam kehidupan rakyat Indonesia sejak zaman nenek moyang.Pada tanggal 22 Juni 1945, Panitia Sembilan berhasil merumuskan Rancangan pembukaan Hukum Dasar, yang oleh Mr. M. Yamin dinamakan Jakarta Charter atau Piagam Jakarta. Di dalam rancangan pembukaan alinea keempat terdapat rumusan Pancasila yang tata urutannya tersusun secara sistematis:

1. Ketuhanan dengan kewajiban menjalankan syari'at Islam bagi pemeluk-pemeluknya

2. Kemanusiaan yang adil dan beradab

3. Persatuan Indonesia

4. Kerakyatan yang dipimpin oleh hikmat kebijaksanaan dalam permusyawaratan perwakilan 
5. Keadilan sosial bagi seluruh rakyat Indonesia

Selain itu, dalam piagam Jakarta pada alenia ketiga juga memuat rumusan teks Proklamasi Kemerdekaan Indonesia yang pertama berbunyi "Atas berkat rahmat Allah Yang Maha Kuasa dan dengan didorongkan oleh keinginan luhur, supaya berkehidupan kebangsaan yang bebas, maka rakyat Indonesia dengan ini menyatakan kemerdekaannya”. Kalimat ini merupakan cetusan hati nurani bangsa Indonesia yang diungkapkan sebelum Proklamasi kemerdekaan, sehingga dapat disebut sebagai declarationof Indonesian Independence.

\section{Pancasila Era Kemerdekaan}

Bangsa Indonesia pasca kemerdekaan mengalami banyak perkembangan. Sesaat setelah kemerdekaan Indonesia pada 1945, Pancasila melewati masa-masa percobaan demokrasi. Pada waktu itu, Indonesia masuk ke dalam era percobaan demokrasi multi-partai dengan sistem kabinet parlementer. Partai-partai politik pada masa itu tumbuh sangat subur, dan proses politik yang ada cenderung selalu berhasil dalam mengusung kelima sila sebagai dasar negara (Somantri, 2006). Pancasila pada masa ini mengalami masa kejayaannya. Selanjutnya, pada akhir tahun 1959, Pancasila melewati masa kelamnya dimana Presiden Soekarno menerapkan sistem demokrasi terpimpin. Pada masa itu, presiden dalam rangka tetap memegang kendali politik terhadap berbagai kekuatan mencoba untuk memerankan politik integrasi paternalistik (Somantri, 2006). Pada akhirnya, sistem ini seakan mengkhianati nilainilai yang ada dalam Pancasila itu sendiri, salah satunya adalah sila permusyawaratan.

Kemudian, pada 1965 terjadi sebuah peristiwa bersejarah di Indonesia dimana partai komunis berusaha melakukan pemberontakan. Pada 11 Maret 1965, Presiden Soekarno memberikan wewenang kepada Jenderal Suharto atas Indonesia. Ini merupakan era awal orde baru dimana kemudian Pancasila mengalami mistifikasi. Pancasila pada masa itu menjadi kaku dan mutlak pemaknaannya. Pancasila pada masa pemerintahan presiden Soeharto kemudia menjadi corevalues (Somantri, 2006), yang pada akhirnya kembali menodai nilai-nilai dasar yang sesungguhnya terkandung dalam Pancasila itu sendiri. Pada 1998, pemerintahan presiden Suharto berakhir dan Pancasila kemudian masuk ke dalam era baru yaitu era demokrasi, hingga hari ini.

\section{Pancasila Era Orde Lama}

Pancasila sebagai idiologi Negara dan falsafah bangsa yang pernah dikeramatkan dengan sebutan azimat revolusi bangsa, pudar untuk pertama kalinya pada akhir dua dasa warsa setelah proklamasi kemerdekaan. Meredupnya sinar api pancasila sebagai tuntunan hidup berbangsa dan bernegara bagi jutaan orang diawali oleh kahendak seorang kepala pemerintahan yang terlalu gandrung pada persatuan dan kesatuan. Kegandrungan tersebut diwujudkan dalam bentuk membangun kekuasaan yang terpusat, agar dapat menjadi pemimpin bangsa yang dapat menyelesaikan sebuah revolusi perjuangan melawan penjajah (nekolim, neokolonialisme) serta ikut menata dunia agar bebas dari penghisapan bangsa atas bangsa dan penghisapan manusia dengan manusia.

Orde lama berlangsung dari tahun 1959-1966. Pada masa itu berlaku demokrasi terpimpin. Setelah menetapkan berlakunya kembali UUD 1945, Presiden Soekarno meletakkan dasar 
kepemimpinannya. Yang dinamakan demokrasi terimpin yaitu demokrasi khas Indonesia yang dipimpin oleh hikmat kebijaksanaan dalam permusyawaratan perwakilan. Demokrasi terpimpin dalam prakteknya tidak sesuai dengan makna yang terkandung didalamnya dan bahkan terkenal menyimpang. Dimana demokrasi dipimpin oleh kepentingan-kepentingan tertetu.

Masa pemerintahan Orde Lama, kehidupan politik dan pemerintah sering terjadi penyimpangan yang dilakukan Presiden dan juga MPRS yang bertentangan dengan pancasila dan UUD 1945. Artinya pelaksanaan UUD1945 pada masa itu belum dilaksanakan sebagaimana mestinya. Hal ini terjadi karena penyelenggaraan pemerintahan terpusat pada kekuasaan seorang presiden dan lemahnya control yang seharusnya dilakukan DPR terhadap kebijakan-kebijakan.

Selain itu, muncul pertentangan politik dan konflik lainnya yang berkepanjangan sehingga situasi politik, keamanaan dan kehidupan ekonomi makin memburuk puncak dari situasi tersebut adalah munculnya pemberontakan G30S/PKI yang sangat membahayakan keselamatan bangsa dan Negara.

Mengingat keadaan makin membahayakan Ir. Soekarno selaku presiden RI memberikan perintah kepada Letjen Soeharto melalui Surat Perintah 11 Maret 1969 (Supersemar) untuk mengambil segala tindakan yang diperlukan bagi terjaminnya keamanaan, ketertiban dan ketenangan serta kesetabilan jalannya pemerintah. Lahirnya Supersemar tersebut dianggap sebagai awal masa Orde Baru.

\section{Pancasila Era Orde Baru}

Era Orde Baru dalam sejarah republik ini merupakan masa pemerintahan yang terlama, dan bisa juga dikatakan sebagai masa pemerintahan yang paling stabil. Stabil dalam artian tidak banyak gejolak yang mengemuka, layaknya keadaan dewasa ini. Stabilitas yang diiringi dengan maraknya pembangunan di segala bidang. Era pembangunan, era penuh kestabilan, menimbulkan romantisme dari banyak kalangan.

Diera Orde Baru, yakni stabilitas dan pembangunan, serta merta tidak lepas dari keberadaan Pancasila. Pancasila menjadi alat bagi pemerintah untuk semakin menancapkan kekuasaan di Indonesia. Pancasila begitu diagung-agungkan; Pancasila begitu gencar ditanamkan nilai dan hakikatnya kepada rakyat; dan rakyat tidak memandang hal tersebut sebagai sesuatu yang mengganjal.

Menurut Hendro Muhaimin bahwa Pemerintah di era Orde Baru sendiri terkesan "menunggangi" Pancasila, karena dianggap menggunakan dasar negara sebagai alat politik untuk memperoleh kekuasaan. Disamping hal tersebut, penanaman nilai-nilai Pancasila di era Orde Baru juga dibarengi dengan praktik dalam kehidupan sosial rakyat Indonesia.

Kepedulian antarwarga sangat kental, toleransi di kalangan masyarakat cukup baik, dan budaya gotong-royong sangat dijunjung tinggi. Selain penanaman nilai-nilai tersebut dapat dilihat dari penggunaan Pancasila sebagai asas tunggal dalam kehidupan berorganisasi, yang menyatakan bahwa semua organisasi, apapun bentuknya, baik itu organisasi masyarakat, komunitas, perkumpulan, dan sebagainya haruslah mengunakan Pancasila sebagai asas utamanya. 
Pada era Orde Baru sebagai era "dimanis-maniskannya" Pancasila. Secara pribadi, Soeharto sendiri seringkali menyatakan pendapatnya mengenai keberadaan Pancasila, yang kesemuanya memberikan penilaian setinggi-tingginya terhadap Pancasila. Ketika Soeharto memberikan pidato dalam Peringatan Hari Lahirnya Pancasila, 1 Juni 1967. Soeharto mendeklarasikan Pancasila sebagai suatu force yang dikemas dalam berbagai frase bernada angkuh, elegan, begitu superior. Dalam pidato tersebut, Soeharto menyatakan Pancasila sebagai "tuntunan hidup", menjadi "sumber tertib sosial" dan "sumber tertib seluruh perikehidupan", serta merupakan "sumber tertib negara" dan "sumber tertib hukum". Kepada pemuda Indonesia dalam Kongres Pemuda tanggal 28 Oktober 1974, Soeharto menyatakan, "Pancasila janganlah hendaknya hanya dimiliki, akan tetapi harus dipahami dan dihayati!" Dapat dikatakan tidak ada yang lebih kuat maknanya selain Pancasila di Indonesia, pada saat itu, dan dalam era Orde Baru.

\section{Pancasila Era Reformasi}

Memahami peran Pancasila di era reformasi, khususnya dalam konteks sebagai dasar negara dan ideologi nasional, merupakan tuntutan hakiki agar setiap warga negara Indonesia memiliki pemahaman yang sama dan akhirnya memiliki persepsi dan sikap yang sama terhadap kedudukan, peranan dan fungsi Pancasila dalam kehidupan bermasyarakat, berbangsa dan bernegara.

Pancasila sebagai paradigma ketatanegaraan artinya pancasila menjadi kerangka berpikir atau pola berpikir bangsa Indonesia, khususnya sebagai dasar negara ia sebagai landasan kehidupan berbangsa dan bernegara. Sebagai negara hukum, setiap perbuatan baik dari warga masyarakat maupun dari pejabat-pejabat harus berdasarkan hukum, baik yang tertulis maupun yang tidak tertulis. Dalam kaitannya dalam pengembangan hukum, Pancasila harus menjadi landasannya. Artinya hukum yang akan dibentuk tidak dapat dan tidak boleh bertentangan dengan sila-sila Pancasila. Substansi produk hukumnya tidak bertentangan dengan sila-sila pancasila.

Memahami peran Pancasila di era reformasi, khususnya dalam konteks sebagai dasar negara dan ideologi nasional, merupakan tuntutan hakiki agar setiap warga negara Indonesia memiliki pemahaman yang sama dan akhirnya memiliki persepsi dan sikap yang sama terhadap kedudukan, peranan dan fungsi Pancasila dalam kehidupan bermasyarakat, berbangsa dan bernegara. Semenjak ditetapkan sebagai dasar negara (oleh PPKI 18 Agustus 1945), Pancasila telah mengalami perkembangan sesuai dengan pasang naiknya sejarah bangsa Indonesia (Koento Wibisono, 2001) memberikan tahapan perkembangan Pancasila sebagai dasar negara dalam tiga tahap yaitu :

\section{Tahap 1945 - 1968 Sebagai Tahap Politis}

Orientasi pengembangan Pancasila diarahkan kepada NationandCharacterBuilding. Hal ini sebagai perwujudan keinginan bangsa Indonesia untuk survival dari berbagai tantangan yang muncul baik dalam maupun luar negeri, sehingga atmosfir politik sebagai panglima sangat dominan. Pancasila sebagai Dasar Negara misalnya menurut Notonagoro dan Driarkara. Kedua ilmuwan tersebut menyatakan bahwa Pancasila mampu dijadikan pangkal sudut pandang dalam mengembangkan ilmu pengetahuan dan bahkan Pancasila merupakan suatu paham atau aliran filsafat Indonesia, dan ditegaskan bahwa Pancasila merupakan rumusan ilmiah filsafati tentang manusia dan realitas, sehingga Pancasila tidak lagi dijadikan alternatif 
melainkan menjadi suatu imperatif dan suatu philosophicalconcensus dengan komitmen transenden sebagai tali pengikat kesatuan dan persatuan dalam menyongsong kehidupan masa depan bangsa yang Bhinneka Tunggal Ika. Bahkan Notonagoro menyatakan bahwa Pembukaan UUD 1945 merupakan staat fundamental Norm yang tidak dapat diubah secara hukum oleh siapapun. Sebagai akibat dari keberhasilan mengatasi berbagai tantangan baik dari dalam maupun dari luar negeri, masa ini ditandai oleh kebijakan nasional yaitu menempatkan Pancasila sebagai asas tunggal.

\section{Tahap 1969 - 1994 Sebagai Tahap Pembangunan Ekonomi}

Upaya mengisi kemerdekaan melalui program-program ekonomi. Orientasi pengembangan Pancasila diarahkan pada bidang ekonomi, akibatnya cenderung menjadikan ekonomi sebagai ideologi. Pada tahap ini pembangunan ekonomi menunjukkan keberhasilan secara spektakuler, walaupun bersamaan dengan itu muncul gejala ketidakmerataan dalam pembagian hasil pembangunan. Kesenjangan sosial merupakan fenomena yang dilematis dengan program penataran P4 yang selama itu dilaksanakan oleh pemerintah. Keadaan ini semakin memprihatinkan setelah terjadinya gejala KKN dan Kronisme yang bertentangan dengan nilai-nilai Pancasila. Bersamaan dengan itu perkembangan perpolitikan dunia, setelah hancurnya negara-negara komunis, lahirnya tiga raksasa kapitalisme dunia yaitu Amerika Serikat, Eropa dan Jepang. Oleh karena itu Pancasila sebagai dasar negara tidak hanya dihantui oleh supersifnya komunisme melainkan juga harus berhadapan dengan gelombang aneksasinya kapitalisme, disampingmenhadapi tantangan baru yaitu KKN dan kronisme.

\section{Tahap 1995 - 2020 Sebagai Tahap Repositioning Pancasila}

Dunia masa kini sedang dihadapi kepada gelombang perubahan secara cepat, mendasar, spektakuler, sebagai implikasi arus globalisasi yang melanda seluruh penjuru dunia, khususnya di abad XXI sekarang ini, bersamaan arus reformasi yang sedang dilakukan oleh bangsa Indonesia. Reformasi telah merombak semua segi kehidupan secara mendasar, maka semakin terasa orgensinya untuk menjadi Pancasila sebagai dasar negara dalam kerangka mempertahankan jatidiri bangsa dan persatuan dan kesatuan nasional, lebih-lebih kehidupan perpolitikan nasional yang tidak menentu di era reformasi ini. Berdasarkan hal tersebut diatas perlunya reposisi Pancasila yaitu reposisi Pancasila sebagai dasar negara yang mengandung makna Pancasila harus diletakkan dalam keutuhannya dengan Pembukaan UUD 1945, dieksplorasikan pada dimensi-dimensi yang melekat padanya.

Di era reformasi ini, Pancasila seakan tidak memiliki kekuatan mempengaruhi dan menuntun masyarakat. Pancasila tidak lagi populer seperti pada masa lalu. Elit politik dan masyarakat terkesan masa bodoh dalam melakukan implementasi nilai-nilai pancasila dalam kehidupan berbangsa dan bernegara. Pancasila memang sedang kehilangan legitimasi, rujukan dan elan vitalnya. Sebab utamannya karena rejim Orde Lama dan Orde Baru menempatkan Pancasila sebagai alat kekuasaan yang otoriter.

Terlepas dari kelemahan masa lalu, sebagai konsensus dasar dari berdirinya bangsa ini, yang diperlukan dalam konteks era reformasi adalah pendekatan-pendekatan yang lebih konseptual, komprehensif, konsisten, integratif, sederhana dan relevan dengan perubahanperubahan yang terjadi dalam kehidupan masyarakat, bangsa dan negara. 


\section{C.Kesimpulan}

Pancasila sebagai dasar filsafat negara Republik Indonesia ,Pancasila adalah lima nilai dasar luhur yang ada dan berkembang bersama dengan bangsa Indonesia sejak dahulu. Sejarah merupakan deretan peristiwa yang saling berhubungan. Peristiwa-peristiwa masa lampau yang berhubungan dengan kejadian masa sekarang dan semuanya bermuara pada masa yang akan datang. Hal ini berarti bahwa semua aktivitas manusia pada masa lampau berkaitan dengan kehidupan masa sekarang untuk mewujudkan masa depan yang berbeda dengan masa yang sebelumnya. Sejarah perjuangan bangsa Indonesia berlalu dengan melewati suatu proses waktu yang sangat panjang. Dalam proses waktu yang panjang itu dapat dicatat kejadiankejadian penting yang merupakan tonggak sejarah perjuangan.

Dasar Negara merupakan alas atau fundamen yang menjadi pijakan dan mampu memberikan kekuatan kepada berdirinya sebuah Negara. Negara Indonesia dibangun juga berdasarkan pada suatu landasan atau pijakan yaitu pancasila. Pancasila, dalam fungsinya sebagai dasar Negara, merupakan sumber kaidah hukum yang mengatur Negara Replubik Indonesia, termasuk di dalamnya seluruh unsur-unsurnya yakni pemerintah, wilayah, dan rakyat. Pancasila dalam kedudukannya seperti inilah yang merupakan dasar pijakan penyelenggaraan Negara dan seluruh kehidupan Negara Replubik Indonesia.

\section{DAFTAR PUSTAKA}

Darmini Roza dan Laurensius Arliman S Peran Pemerintah Daerah Di Dalam Melindungi Hak Anak Di Indonesia, Masalah-Masalah Hukum, Volume 47, Nomor 1, 2018.

Laurensius Arliman S, Komnas HAM dan Perlindungan Anak Pelaku Tindak Pidana, Deepublish, Yogyakarta, 2015.

Laurensius Arliman S, Penguatan Perlindungan Anak Dari Tindakan Human Trafficking Di Daerah Perbatasan Indonesia, Jurnal Selat, Volume 4, Nomor 1, 2016.

Laurensius Arliman S, Problematika Dan Solusi Pemenuhan Perlindungan Hak Anak Sebagai Tersangka Tindak Pidana Di Satlantas Polresta Pariaman, Justicia Islamica, Volume 13, Nomor 2, 2016.

Laurensius Arliman S, Pelaksanaan Perlindungan Anak Yang Tereksploitasi Secara Ekonomi Oleh Pemerintah Kota Padang, Veritas et Justitia, Volume 2, Nomor 1, 2016. 
Laurensius Arliman S, Kedudukan Ketetapan MPR Dalam Hierarki Peraturan PerundangUndangan Di Indonesia, Lex Jurnalica, Volume 13, Nomor 3, 2016.

Laurensius Arliman S, Komnas Perempuan Sebagai State Auxialiary Bodies Dalam Penegakan Ham Perempuan Indonesia, Justicia Islamica, Volume 14, Nomor 2, 2017.

Laurensius Arliman S, Peranan Pers Untuk Mewujudkan Perlindungan Anak Berkelanjutan Di Indonesia, Jurnal Ilmu Hukum Tambun Bungai, Volume 2, Nomor 2, 2017.

Laurensius Arliman S, Mewujudkan Penegakan Hukum Yang Baik Untuk Mewujudkan Indonesia Sebagai Negara Hukum, Jurnal Hukum Doctrinal, Volume 2, Nomor 2, 2017.

Laurensius Arliman S, Participation Non-Governmental Organization In Protecting Child Rights In The Area Of Social Conflict, The 1st Ushuluddin and Islamic Thought International Conference (Usicon), Volume 1, 2017.

Laurensius Arliman S, Partisipasi Masyarakat Dalam Pembentukan Perundang-Undangan Untuk Mewujudkan Negara Kesejahteraan Indonesia, Jurnal Politik Pemerintahan Dharma Praja, Volume 10, Nomor 1, 2017, https://doi.org/10.33701/jppdp.v10i1.379.

Laurensius Arliman S, Peran Komisi Perlindungan Anak Indonesia Untuk Mewujudkan Perlindungan Anak, Jurnal Respublica Volume 17, Nomor 2, 2018.

Laurensius Arliman S, Menjerat Pelaku Penyuruh Pengrusakan Barang Milik Orang Lain Dengan Mempertimbangkan Asas Fungsi Sosial, Jurnal Gagasan Hukum, Volume 1, Nomor 1, 2019.

Laurensius Arliman S, Ilmu Perundang-Undangan Yang Baik Untuk Negara Indonesia, Deepublish, Yogyakarta, 2019.

Laurensius Arliman S, Isdal Veri, Gustiwarni, Elfitrayenti, Ade Sakurawati, Yasri, Pengaruh Karakteristik Individu, Perlindungan Hak Perempuan Terhadap Kualitas Pelayanan Komnas Perempuan Dengan Kompetensi Sumber Daya Manusia Sebagai Variabel Mediasi, Jurnal Menara Ekonomi: Penelitian dan Kajian Ilmiah Bidang Ekonomi, Volume 6, Nomor 2, 2020. 
Laurensius Arliman S, Pendidikan Kewarganegaraan, Deepublish, Yogyakarta, 2020.

Laurensius Arliman S, Makna Keuangan Negara Dalam Pasal Pasal 23 E Undang-Undang Dasar 1945, Jurnal Lex Librum, Volume 6, Nomor 2 Juni 2020, http://dx.doi.org/10.46839/1ljih.v6i2.151.

Laurensius Arliman S, Kedudukan Lembaga Negara Independen Di Indonesia Untuk Mencapai Tujuan Negara Hukum, Kertha Semaya Journal Ilmu Hukum, Volume 8, Nomor 7, 2020.

Laurensius Arliman S, Pelaksanaan Assesment Oleh Polres Kepulauan Mentawai Sebagai Bentuk Pelaksanaan Rehabilitasi Bagi Pecandu Dan Korban Penyalahgunaan Narkotika, Jurnal Muhakkamah, Volume 5, Nomor 1, 2020.

Laurensius Arliman S, Aswandi Aswandi, Firgi Nurdiansyah, Laxmy Defilah, Nova Sari Yudistia, Ni Putu Eka, Viona Putri, Zakia Zakia, Ernita Arief, Prinsip, Mekanisme Dan Bentuk Pelayanan Informasi Kepada Publik Oleh Direktorat Jenderal Pajak, Volume 17, No Nomor, 2020.

Larensius Arliman S, Koordinasi PT. Pegadaian (Persero) Dengan Direktorat Reserse Narkoba Polda Sumbar Dalam Penimbangan Barang Bukti Penyalahgunaan Narkotika, UIR Law Review, Volume 4, Nomor 2, 2020, https://doi.org/10.25299/uirlrev.2020.vol4(1).3779.

Laurensius Arliman S, Tantangan Pendidikan Kewarganegaraan Pada Revolusi 4.0, Ensiklopedia Sosial Review, Volume 2, Nomor 3, 2020.

Muhammad Afif dan Laurensius Arliman S, Protection Of Children's Rights Of The Islamic And Constitutional Law Perspective Of The Republic Of Indonesia, Proceeding: Internasional Conference On Humanity, Law And Sharia (Ichlash), Volume 1, Nomor 2, 2020.

Otong Rosadi danLaurensius Arliman S, Urgensi Pengaturan Badan Pembinaan Idelogi Pancasila Berdasarkan Undang-Undang Sebagai State Auxiliary Bodies yang Merawat Pancasila dalam Perspektif Hak Asasi Manusia, Prosiding Konferensi Nasional Hak Asasi Manusia, Kebudayaan dan Tujuan Pembangunan Berkelanjutan Indonesia pada Masa Pandemi Covid19: Tantangan untuk Keilmuan Hukum dan Sosial Volume 1, Universitas Pancasila, Jakarta, 2020 . 